

Barg, K . (2015) Educational choice and cultural capital: examining social stratification within an institutionalized dialogue between family and school. Sociology, 49(6), pp. 1113-1132.

There may be differences between this version and the published version. $Y$ ou are advised to consult the publisher's version if you wish to cite from it.

http://eprints.gla.ac.uk/103554/

Deposited on: 08 February 2016

Enlighten - R esearch publications by members of the U niversity of Glasgow http://eprints.gla.ac.uk 


\section{Title: Educational choice and cultural capital: Examining social stratification within an}

institutionalized dialogue between family and school

Corresponding author: Katherin Barg

Email of corresponding author: Katherin.Barg@glasgow.ac.uk

Address of corresponding author:

University of Glasgow

School of Education

11, Eldon Street

G36NH Glasgow

Abstract: This paper analyses the impact of social class on families' and teachers' decisionmaking within an institutionalized family-school dialogue in France. The dialogue decides which upper secondary school track a student will attend and consists of three main steps: (i) family's school track request, (ii) staff meeting's subsequent school track proposition, and (iii) family's optional rejection of the staff's proposition. Using national longitudinal data, I find that parents' cultural capital importantly mediates secondary effects (i.e. social class effects that remain after controlling for school performance) on families' requests and their rejections of staffs' propositions. Social class effects on staffs' propositions are accounted for by families' requests and student school performance. Moreover families and teachers appear to choose grade retention to avoid enrolment in a lower track.

Keywords: Cultural capital, Education, Rational choice, School track choice, Social class 


\section{Introduction}

To examine why social class differentials in educational attainment are still evident, rational choice theories on educational decision-making of students and their parents have been developed (Breen and Goldthorpe, 1997; Erikson and Jonsson, 1996; Esser, 1999). Researchers apply these theories to educational decisions such as secondary school track choices (e.g. Stocké, 2007) or tertiary education decisions (e.g. Becker and Hecken, 2009). However, depending on the institutional regulation of transitions from one educational level to another, students and their parents often do not have the only word. In France, an institutionalized dialogue between family and school generates the decision on which upper secondary school track a student will attend. This dialogue consists of several steps. First, families make a school track request. Aside from a general track and two different vocational tracks, families can request grade retention. Second, the staff meeting makes a school track proposition, which, again, can be one of these options. Third, if a family's request and the staff meeting's proposition do not correspond, families can reject the proposition. They then have to attend a talk with the headteacher and based on this talk the headteacher makes a decision. Families can reject the headteacher's decision. In this case, a 'recall meeting' of external teachers, other professionals and the headteacher takes the final binding decision.

This institutionalized dialogue was implemented in the 1970s and 1980s amidst reforms that aimed at reducing social inequality of educational opportunity. Prior to the dialogue's implementation, only teachers made the school track decisions. Although the dialogue was supposed to reduce social inequality by increasing families’ decision-making power, social background still has a strong impact on transition rates to general upper secondary school in France, even when student school performance is controlled (e.g. Duru-Bellat and Kieffer, 2001; Ichou and Vallet, 2013). Empirical analyses of the dialogue shed light on one cause of this remaining social origin effect: In most cases, teachers accept families’ requests and 
thereby reproduce the social inequality that comes with families' requests (Duru-Bellat, Jarousse and Mingat, 1993; Duru-Bellat and Mingat, 1989; Roux and Davaillon, 2001; Barg 2013).

These findings are in line with results of international research on educational decisions of families and teachers. They reveal strong 'secondary effects' - i.e. social origin effects that remain when student school performance is held constant (Boudon, 1974) - on families' school track requests and, similar to studies on school track recommendations by German primary teachers, they show that teacher decisions are strongly affected by families' aspirations (e.g. Dollmann, 2011). Beyond that, a detailed analysis of the dialogue can show whether families choose grade retention as a means to avoid enrolment in a lower track (Duru-Bellat, Jarousse and Mingat, 1993; Kloosterman and De Graaf, 2010; Roux and Davaillon, 2001) and whether teachers propose grade retention as a 'compromise' to higherclass families whose children are not good enough to attend the general track (Duru-Bellat, 1996; Roux and Davaillon, 2001). However, previous analyses of the dialogue rest on insufficient data that provides no valid information on student school performance or does not take into account students who already have repeated grades (Roux and Davaillon, 2001). Also, they focus only on parts of the dialogue, do not analyse social class effects on families' rejections of staff meetings' propositions or their retention decisions (Duru-Bellat, Jarousse and Mingat, 1993; Duru-Bellat and Mingat, 1989; Barg 2013).

The present study extends existing research through richer more recent data and a theoretically elaborate approach to social class effects on the first three steps of the dialogue: (i) families' requests, (ii) staff meetings' propositions and (iii) families' rejection decisions. I use national longitudinal data - the panel d'élèves du second degré (1995-2001) - on a large cohort of students who entered lower secondary education in 1995. Since the data provide information on students' family background, school performance and every step of the 
dialogue, I am able to conduct a detailed analysis of families’ and staff meetings’ decisions, including their school track and grade retention decisions, and families' rejections of staff meetings' propositions.

This paper is structured as follows: section 2 provides a presentation of the dialogue's institutional context. Section 3 deals with the theoretical approach to families' and staff meetings' decision-making. Section 4 addresses data, variables and method. Section 5 presents the empirical results and section 6 concludes.

\section{The institutional context}

In France, primary education starts at the age of 6 and secondary education at the age of 10 or 11 (OECD, 1996: 273-276). Up to grade 9, students attend lower secondary education and jointly visit the collège. Lower secondary education ends with the centralized brevet-exam. Successfully passing the exam is rewarded with the brevet, i.e. the certificate of lower secondary education. The exam consists of two parts: The 'continuous examination' during grade 8 and 9 and a written and oral exam at the end of grade 9. Students' marks during grade 8 and 9 determine their score on the 'continuous examination'. This score typically represents 60 to 63 per cent of the final score (DEPP, 2008).

After grade 9, students follow up their education in the general or vocational upper secondary school track. These chosen tracks are decided via the institutionalized dialogue between family and school. The general track is further divided into an academic track that ends with the 'general baccalauréat' and a more professional track that leads to the 'technological baccalauréat' after three grades. The school that provides the two tracks is the lycée général et technologique (LGT). Students can also attain a ‘technician’s diploma’ if they complete two grades of the more professional track. In the vocational upper secondary school track, 
students attend the lycée professionnel (LP). A successful completion of two grades in this track leads to the vocational certificates CAP ('Certificate of Vocational Aptitude') or BEP ('Diploma of Vocational Studies'). Four grades in this track are rewarded with a 'professional baccalauréat'. All baccalauréat-diplomas provide access to higher education (OECD, 1996: 273-276). However, while students with a 'general baccalauréat' more often go to university, their peers with a 'technological baccalauréat' rather opt for vocational higher education. The $B E P$ has a more theoretical foundation and provides a broader qualification than the CAP but both certificates formally have the same 'value' (Brauns and Steinmann, 1999: 13-14). I therefore combine both tracks to one vocational track LPA. At step 1 of the dialogue (family's request) and at step 2 (staff meeting's proposition) the actors then choose between the general track (LGT), the vocational track (LPA) and grade retention (GR). At step 3, families can choose to reject the staff meeting's proposition.

To understand the school staff's decision-making within the dialogue, it is important to note that every school year schools have to report to administrative authorities grade retention rates, final outcomes of the dialogue and rates of discrepancies between families' requests and staff meetings' propositions (Masson, 1994, 1997). The authorities generally require the schools to keep retention and rejection rates low. The rates are published and the public uses them as 'school quality'-indicators.

\section{Theoretical background and hypotheses}

\section{Family's decision-making}

To theoretically address why social classes differ with regard to the decisions they make within the dialogue, I apply the seminal rational choice models on educational decisionmaking (Boudon, 1974; Breen and Goldthorpe, 1997; Erikson and Jonsson, 1996; Esser, 
1999). The common core of these models is their assumption that students and their parents evaluate 'costs' of attending a specific educational track, 'benefits' of doing so and the probability that a student successfully completes that specific track. The 'costs' typically include direct monetary costs, e.g. for learning material, and indirect costs such as forgone earnings due to a later entry into the labour market. The central component of the 'benefits' is the utility that a specific educational track leads to an educational attainment and later to an occupation that enables a family to preserve its social class position. This motive of status maintenance is termed 'relative risk aversion' in the model by Breen and Goldthorpe (1997). Boudon (1974) and Erikson and Jonsson (1996) also assign social and cultural components to the benefits (e.g. keeping in contact with peers, the mere pleasure of attending general education).

Social class differences in families’ decisions emerge through three mechanisms: First, since students from higher social classes perform, on average, better in school than students from lower classes, they are more likely to successfully complete the general track than lower-class students. Second, families of higher social class position are better equipped with economic resources and as such are better able to bear the costs of higher and longer educational pathways. Third, higher-class students need to attend higher educational tracks in order to maintain their family's social position, while lower-class students do not. For instance, if higher-class students do not complete a university education, their families are very likely to experience downward mobility; working-class students will be able to preserve their families’ social position if they complete 'only' an apprenticeship.

Within the dialogue, families consider also a fourth component: They additionally evaluate the likelihood that the school will accept their request. To assess this likelihood, parents take into account their investment in persuading teachers of their children's abilities and of their capacities to support them. They also consider their own willingness and capacity to reject the 
staff meeting's proposition, to persuade the headteacher and to follow the dialogue through its end, in case the meeting does not accept their request. Therefore, a fourth mechanism contributes to the generation of social class effects on families' decisions: Social class differences in parents' cultural capital in terms of their formal and informal knowledge of the education system and their confidence and ability in dealing with school staff. This mechanism is based upon a theoretical suggestion advanced by Lareau and Weininger (2003) on the role of cultural capital in family-school interactions. They argue that parents with higher educational attainment and from higher social classes are more confident in the school context, interact more easily with school staff, are generally more involved in school, may put more pressure on teachers and therefore acquire preferable treatment for their children. Qualitative studies (e.g. Horvat, Weininger and Lareau, 2003) and quantitative studies (e.g. Cheadle and Amato, 2011) support this argument. Accordingly, parents from higher social classes are more likely to persuade their children's teachers and to possess the capacity and willingness to reject the staff meeting's proposition and talk with the headteacher than lowerclass parents. This yields two hypotheses: first, given the same school performance level, social class has a strong positive effect on the likelihood that a family requests LGT instead of LPA (H1); second, this social class effect is partly mediated by parents' cultural capital (H1a).

The theoretical model further provides a foundation for understanding social class effects on families' decisions to choose grade retention (GR) over LPA when a student is poorly performing. Since a low performance level indicates that a student is not likely to succeed in LGT and that the risk is high that the staff meeting will not accept an LGT-request, families that need their child to complete LGT in order to preserve their social status, choose GR. Doing so, they give their children the chance to improve during repetition and to be admitted to LGT one year later. Hence, since families from higher classes cannot maintain their social 
position if their child does not complete LGT while lower-class families can, higher-class families are more likely to request GR instead of LPA (see also Kloosterman and De Graaf, 2010). Two mechanisms further strengthen this social class effect: First, higher social classes have the economic and cultural resources that are necessary to bear 'costs of grade retention' (e.g. foregone earnings, student's lowered self-esteem); second, as students from lower classes are more likely to have repeated grades before, their parents are less likely to consider repetition of another grade as an option. Hence, I derive that, at low school performance levels, social class has a strong positive effect on the likelihood that a family requests GR instead of LPA (H2).

The theoretical model can further explain social class differences in families' decisions to reject staff meetings' propositions. Since higher-class families have a higher 'relative risk aversion', they are more willing to make the effort of rejecting the staff meeting's proposition. Here, the fourth mechanism - i.e. social class differences in parents' cultural capital - plays a key role because parents evaluate their chances to persuade the headteacher and the psychological effort of talking with him. Since parents from higher classes are more familiar with the school context than parents from lower classes, they are more confident and dealing with school staff means less effort for them than for lower-class families. Against this background, I assume: among families who requested LGT but were proposed LPA or GR, social class has a positive effect on the likelihood that a family rejects the staff meeting's proposition (H3) and this effect is considerably mediated by parents' cultural capital (H3a).

\section{Staff meeting's decision-making}

To explain why social class affects the staff meeting's proposition, I propose that the staff evaluates four factors (Barg 2013): student's chances to successfully complete a specific school track, the probability that parents reject their proposition, 'benefits' of choosing a specific track and corresponding 'costs'. The 'benefits' include, for instance, professional 
satisfaction for having taken an appropriate decision, for acting according to the legal regulations of the dialogue and for meeting the requirements by the governmental authorities. The possible 'costs' can include disapproval by parents, students or colleagues and a harmed school image due to high rejection rates. To assess a student's chances of success, the school staff considers the student's school performance (Neugebauer, 2010). However, it may also consider 'non-cognitive traits' such as behaviour in class, linguistic abilities and work habits (Bowles and Gintis, 1976). From ascriptive traits such as social class or parental education teachers may directly derive parents' capacity and willingness to help their children with school issues (Duru-Bellat, 1996). In order to evaluate the probability that a family rejects the staff meeting's proposition, the staff meeting considers the family's request and family traits that indicate parents' willingness and capacity to make the effort of rejecting and meeting the headteacher. Such traits are parents' educational attainment and social class position, their involvement in school (e.g. initiation of meetings with teachers) and attempts to influence the teachers.

The effect of class origin on their decision to propose LGT instead of LPA emerges through three mechanisms: First, since social class is positively correlated with student performance, more higher-class students are perceived to be capable of successfully completing the LGT. Second, due to the positive association between social class and the likelihood that a family requests LGT, staff meetings do more often propose LGT to higher-class families because they follow the legal texts and because they consider these families to be likely to reject their proposition (if this was LPA). Third, since higher social classes are better equipped with cultural capital, they are more likely to be involved in their children's schooling, to initiate meetings with teachers and to try to influence them. On the one hand, they are therefore more likely to indicate that they have the capacity to help their child with school issues. On the other hand, they appear more likely to reject the staff meeting's proposition, meet the 
headteacher and take further steps of the dialogue. Moreover, the effect of class origin on staff meetings' propositions is strengthened if teachers take into account students' non-cognitive ability, which is correlated with social class. This yields two hypotheses: first, holding constant student performance, student social class has a strong positive effect on staff meeting's decision to propose LGT instead of LPA (H4); second, this social class effect is strongly mediated by family's request and parents' cultural capital (H4a).

A similar theoretical reasoning yields the assumption that class origin has a positive effect on the likelihood that staff meetings choose GR over LPA. Typically, a staff meeting faces this type of decision when a student's school performance indicates that she may not successfully complete LGT. In this case, the staff meeting considers the likelihood that a family rejects an LPA-proposition, the probability that the student improves enough during the repeated grade so that she can be admitted to LGT and 'costs' of retaining the student. These 'costs' consist of an increased economic burden for the school and for higher administrative institutions because retention increases class sizes, the need for teachers and for learning material (Schnurr, Kundert and Nickerson, 2009). School staff also wants to avoid high rates of grade repetitions because these indicate that a school system is poorly performing (Ryan and Watson, 2006) and because the French government requires them to be kept low (Masson, 1994, 1997). To assess the probability that students improve during a repeated grade, staff meetings consider students' family background and whether they already have repeated grades. If students were retained previously, they are older than the other students and since they are still not good enough to be admitted to LGT, retaining them obviously has not led to an improvement of their school performance. From students’ family background (e.g. parents’ education) teachers derive parents’ capacities to support their child during repetition.

Three mechanisms drive social class differentials in staff meetings’ GR-propositions: first, since higher-class families are more likely to request LGT, they are more likely to reject if the 
staff meeting proposes LPA. However, they are likely to accept a GR-proposition, especially when their child is not performing well and would face difficulties in LGT. Second, lowerclass students are, on average, more likely to have repeated grades and therefore staff meetings are more likely to believe that another repetition would not help them improve. Third, since higher-class parents have the cultural capital that indicates their capacities and willingness to reject and to support their child during the repeated grade, staff meetings are more likely to propose GR as a compromise to them than to lower-class families. Accordingly, I assume that, at low levels of student school performance and given a family has requested LGT, student social class has a strong positive effect on the likelihood that the staff meeting proposes GR instead of LPA (H5).

\section{Data and methods}

\section{Data}

I use the panel d'élèves du second degré - data that was collected through a representative longitudinal study commissioned by the French Ministry of Education (DEPP, 2008). It observed students who entered the collège in 1995 during their secondary education and beyond. I use information on six time points. In 1995, headteachers of all secondary schools had to report nationality, gender and other identifying characteristics of selected students, and family characteristics such as parents’ professions and nationalities. In 1998, when students

were about to enter grade 9, parents provided information on the family situation (e.g. parents' educational attainments and occupations). In 1999, the survey observed the transition from lower to upper secondary education of students who had not repeated grades since entering lower secondary education. Correspondingly, for 2000 and 2001, this information is provided for students who had repeated one or two grades. At these three time points - 1999, 
2000, 2001 - headteachers reported all steps of the institutionalized dialogue between family and school and students' marks in the 'continuous examination' of the brevet.

The analysis sample excludes students whose families did not take part in the family survey in 1998, students who did not live at least with one parent, for whom the headteacher did not report the dialogue and cases with missing values on all used variables. This reduces the sample of 17,830 students that were first observed in 1995 to $11,623{ }^{1}$ This sample is used for the analysis of families' requests and staff meetings' propositions. For the analysis of families’ rejection decisions, I use a smaller sample of 956 cases including only families who requested LGT but were proposed LPA or GR.

\section{Variables}

I employ three dependent variables: family's request, staff meeting's proposition and family's decision to reject the proposition. The first two variables differentiate between (i) LGT, (ii) LPA and (iii) GR. The rejection-variable indicates families' rejection of the staff meeting's proposition vs. no rejection.

Social class is represented through the EGP-class schema (Erikson and Goldthorpe 1992). The schema is based on the differentiation of occupations according to their labour-market and work situations (Erikson and Goldthorpe 1992: 41) and many studies for different countries found the theoretically expected differentials in educational attainment (e.g., Brauns 1998; Ichou and Vallet 2011 as examples for France). I distinguish six classes: (1) higher service class - EGP I; (2) lower service class - EGP II; (3) routine non-manual workers of lower and higher grade - EGP IIIab - and lower grade technicians and supervisors of manual workers - EGP V; (4) skilled and semi- or unskilled manual workers - EGP VI, VIIa; (5) farmers and agricultural workers - EGP IVc, VIIb; (6) non-agricultural self-employed and petty bourgeoisie - EGP IVab. The working-class (EGP VI, VIIa) includes very few students 
with two parents who never worked, have no occupation, whose occupation cannot be classified or who are unknown or dead. The working-class will be the reference category in the multivariate analyses.

I use information on students' results on the 'continuous exam', which is the average of their marks in grade 8 and 9, to construct a grade point average-variable (GPA). I calculate the average of the marks in French and mathematics. In France, marks typically range from 0 (lowest) to 20 (highest). The grade repetition-variable indicates with ' 1 ' students who have repeated up to two years in lower secondary school and with ' 0 ' students who have not.

As a proxy for parents' cultural capital, I use parents' educational attainment. Parents' education is a reasonable indicator for cultural capital that parents can make use of in their interactions with the school because it indicates how much time they have spent in the educational system and, hence, their experience in communicating with school staff and their formal and informal knowledge of the education system. I combine information on both father and mother in order to take into account the accumulation of resources through both parents and to measure the general level of cultural capital prevailing in the family (Bourdieu, 1966: 326). I build three categories: (1) 'higher education' including students with two parents having at least a bac or one parent with a tertiary diploma; (2) 'intermediate education' containing students with two parents having a CAP or BEP or one parent having a bac; (3) 'lower education' consisting of students with two parents without attainment or one parent with a CAP or BEP.

The multivariate analysis includes four control variables. First, it takes into account student's immigration background. Using information from the family survey on parents' nationality and country of birth, I distinguish between students who have two parents of French nationality who were born in metropolitan France and students with immigration background. The latter group consists of students whose parents originate from the French overseas 
territories and the Maghreb, have a foreign nationality and are born abroad, and parents of mixed origin. Second, a control variable indicates whether a student attends a school located in a ZEP, i.e. an 'education priority zone'. The government supports ZEP-schools, which are located in zones with high rates of disadvantaged families, with extra financial resources and more teaching staff (Bénabou, Kramarz and Prost, 2009). Third, another school-type variable denotes students who attend a private school. Fourth, I take into account the size of the city in which a school is located. In larger cities and notably in Paris there are more 'elite'- and private schools and hence families have more possibilities to influence their children's school career through specific school choices. I employ a variable with four categories: (1) rural to 5,000 inhabitants, (2) 5,000 to 20,000 inhabitants, (3) 20,000 to 200,000 inhabitants and (4) 200,000 to 2,000,000 inhabitants and Paris.

\section{Methods}

I first present bivariate analyses of social class effects on the three outcomes and the central explanatory variables GPA, previous grade repetition and parental education. For the analysis of families’ requests and staff meetings’ propositions, I apply multinomial logistic regression models. By means of binary logistic regression models I examine families' rejection decisions. I present Average Marginal Effects (AME) and illustrate key results with predicted probability plots since comparisons of coefficients such as 'odds-ratios' or 'logits' across nested nonlinear probability models can be confounded by differences in unobserved heterogeneity (e.g. Karlson and Holm, 2011; Mood, 2010). The graphical presentation of predicted probabilities and AMEs are a remedy and make results more understandable (e.g. Long 1997: 64-79; Mood 2010). ${ }^{2}$ 


\section{Results}

\section{Bivariate analysis}

Figure 1 presents the distribution of families' requests, staff meetings' propositions and families' rejection decisions by social class. As expected, the chances of requesting and getting proposed LGT augment with social class position. Among families belonging to EGP I, for instance, 92 per cent demanded LGT, while only 47 per cent of EGP VI, VIIa-families made this request. The relationship between staff meeting's school track proposition and family’s social class highly resembles the corresponding association between family’s social class and family's request. Though, generally chances that the staff meeting proposes LGT are lower than the probabilities that a family requests LGT. Regarding families' rejection decisions, Figure 1 shows that - among families who requested LGT but where proposed LPA or GR - differences between social classes are relatively small. For instance, while 38 per cent of families from EGP I and II decide to reject, 27 per cent from the working class opt for rejection.

\section{FIGURE 1}

Figure 2 and 3 address the associations between social class and grade point average (GPA), previous grade repetition and parental education. The box plot reveals that the mean GPA increases with social class (Figure 2).

\section{FIGURE 2}

Figure 3 shows that the likelihood of having repeated grades decreases with social class and indicates the expected positive association between social class and cultural capital: The percentage of students having a 'high educational background', for instance, is 79 per cent among EGP I-students and only 1 per cent among working class-students. 
FIGURE 3

\section{Multivariate analysis}

Table 1 shows multinomial logistic regression models of families’ requests. Model 1 contains only student social class and the control variables. Regarding families' LGT/LPA-choice, it reveals a highly significant positive effect of social class on families' choices. Including student's GPA and previous grade repetition substantially decreases the social class effect and

increases the model fit (Model 2). ${ }^{3}$ For instance, when student performance is not taken into account, the likelihood that a family from EGP I requests LGT is, on average, 45 percentage points higher than the likelihood that a working class-family does so. When controlling for GPA and previous repetition, the corresponding AME is reduced to 0.25 . The probability that a family requests LGT increases, on average, by 7 percentage points with every additional GPA-point. For students who were retained in lower secondary school the likelihood to request LGT is, on average, 19 percentage points lower than for students who did not repeat. The strong significant effect of EGP-class that remains after controlling for GPA and previous repetition provides evidence in favour of hypothesis $\mathrm{H} 1$ which posits that, holding constant school performance, social class has a strong positive effect on the likelihood that a family requests LGT instead of LPA. Model 3 tests H1a, i.e. the social class effect that remains after controlling for performance is partly mediated by parents' cultural capital. The results support the hypothesis as the social class effect further decreases when parental education is considered. The significant positive coefficients of parental education indicate that parents with a high level of cultural capital are more likely to request LGT. According to the theoretical model, this effect is driven by parents' assessment of the effort they have put in persuading the teachers and their capacities to take the next steps of the dialogue (i.e. reject the staff meeting's or the headteacher's proposition). 


\section{TABLE 1}

With regard to families' GR/LPA-decisions, Model 1 and 2 in Table 1 show that the expected positive effect of social class increases and becomes significant when student school performance is held constant. This is because social class and school performance are positively related, while social class and the probability to request GR are negatively correlated. However, given the same school performance level, families from higher social classes are significantly more likely to request GR than families from EGP VI, VIIa. This result represents basic evidence for $\mathrm{H} 2$, which assumes that, at low school performance levels, social class has a strong positive effect on the probability that a family choose GR over LPA. To illustrate the relationship between GPA, previous grade repetition, social class and families' requests, Figure 4 presents predicted probabilities. Probabilities are calculated for students of native origin and attending a public school that is not located in a ZEP but lies in a larger city or Paris. Providing support for H2, Figure 4 shows that at low levels of GPA and when no previous repetition has occurred families from EGP I are considerably more likely to request GR than working class-families. When a student has repeated grades before, the difference is smaller and retention remains only an option for higher-class families. Model 3 in Table 1 takes into account parental education and reveals that parents' cultural capital considerably drives this social class effect. Parents from higher classes seem more likely to demand GR because they have the cultural resources to support their children during repetition. The remaining social class effect is due, then, to their 'relative risk aversion' and their consideration of economic costs of retention and of student's future attendance of LGT.

\section{FIGURE 4}

Table 2 addresses the staff meetings' decision-making. Comparing the EGP-effects in Model 1 and 2 reveals that a considerable part of these effects is due to student's GPA and previous repetition. The remaining social class effect represents evidence in favour of H4 (i.e. holding 
constant student performance, student social class has a strong positive effect on staff meeting's decision to propose LGT over LPA). In line with literature arguing that teachers make more meritocratic decisions than parents and students, student's performance explains a larger part of the social class effect on staff meetings' propositions than of the social class effect on families' requests. For instance, while the EGP I effect on families' request is reduced almost by one half from 0.45 (Model 1, Table 1) to 0.25 (Model 2, Table 1). The EGP I effect on staff meetings' propositions decreases by more than 60 per cent (compare Model 1 and 2, Table 2). Including family’s request into the analysis of staff meetings' LGTpropositions (Model 3) further increases the model fit and the effect of social class become insignificant. This result partly supports H4a (i.e. holding constant performance, the social class effect is strongly mediated by family's request and parents' cultural capital) and shows that teachers reproduce the secondary effects in families' requests. However, Model 4 provides evidence against the second part of H4a: Parental education has no significant effect and its inclusion does not improve the model fit.

Table 2 also indicates that social class has a highly significant positive effect on the likelihood that the staff meeting proposes GR instead of LPA. Model 2 shows, for instance, that the likelihood that the staff proposes retention to an EGP-I student is, on average, 9 percentage points higher than the corresponding likelihood for a working class-student. This result supports H5, which assumes that, at low performance levels and given a family has requested LGT, social class has a strong positive effect on the likelihood that the staff meeting proposes GR over LPA. Model 3 contains family’s request and reveals that a considerable part of the social class effects on staff meetings' GR-propositions are due to families' requests. As expected, cultural capital mediates the social class effect and has a significant positive effect on the likelihood that the staff meeting proposes GR (Model 4). This effect could be due to staff meetings' 'anxiety' that the family rejects its proposition if this is LPA. Furthermore, the 
staff may consider higher educated parents to be better able to support their child during the repeated grade.

\section{TABLE 2}

To illustrate the relationship between social class, staff meetings' decision and GPA, Figure 5 plots predicted probabilities. They represent native students who requested LGT and attend a public non-ZEP-school located in a larger city or Paris. As predicted by H5, at low levels of GPA, the staff meeting is more likely to propose GR to students from EGP I than to students from EGP VI, VIIa. Beyond that, previous grade repetition appears to 'interact' with social class: When students have not repeated grades previously, staff meetings are willing to propose GR instead of LPA to students from all social classes. By contrast, if students have repeated grades in prior years, the staff meeting is still more likely to choose GR than LPA for a student of higher social origin; for a working class-student, however, teachers will rather choose LPA than GR. This result could indicate that teachers expect higher-class parents to be better able to bear the social and economic costs of another repetition. They may also consider these parents to be more likely to reject an LPA-proposition and lower-class parents to accept the enrolment of their child in the vocational track. Overall, teachers are more willing to choose grade retention than families.

\section{FIGURE 5}

Table 3 addresses families’ decision to reject the staff meeting’s proposition. Model 1, which includes only social class and the control variables, reveals positive effects that are significant at middle and lower levels. As predicted by H3, higher social classes are more likely to reject the staff meetings' proposition if this does not correspond to their request than lower social classes. Model 2 takes into account parental education in order to test H3a, which posits that the social effect is considerably mediated by parents' cultural capital. The results provide 
evidence in favour of this hypothesis as social class effects become insignificant and parents' intermediate educational level has a positive weakly significant effect. This could indicate that parents from higher classes are more likely to reject because they have the cultural resources that give them confidence to meet the headteacher, discuss their child's educational plans and take further steps along the dialogue.

\section{TABLE 3}

\section{Conclusion}

It is a widely established finding that social class strongly affects educational decisions of students and their parents, even when school performance is held constant. The theoretical models that address this 'secondary effect' assume that it is mainly driven by families' consideration of costs, benefits, student's chances of success and their motive of status maintenance. The present study extends these models as it takes into account the institutional context of family's educational decision-making and therefore integrates an additional cultural capital-mechanism. It advances that - under specific institutional circumstances families consider their effort and capacities to persuade school staff and to have their requests accepted. Such circumstances are that the school has important decision-making power and families' possibility to reject the schools' propositions. Indeed, the empirical analysis of families' requests and rejections shows that cultural capital considerably contributes to social class effects on these decisions. Moreover, this study contributes to the scarce research on social class differences in families' use of grade retention to avoid enrolment in a lower track.

I find that families' school track requests fully account for social class effects on teachers' school track propositions net of student school performance and, hence, staff meetings reproduce the social inequality that is generated by social class differences in families' 
educational aspirations. According to the theory, families' requests have such strong effects on teachers' decisions because they want to avoid that families reject their propositions. At the same time, they may simply follow the legal regulations that ask them to take into account students' educational plans. Still, they do not correct too ambitious requests of higher-class families and are more likely to propose grade retention as a compromise to them. However, at high GPA-levels the staff meeting increasingly proposes LGT to families who demanded LPA, regardless of their class. ${ }^{4}$

In terms of policy implications, these findings suggest that institutional opportunities such as grade retention and rejection options should be reassessed in the light of the social inequality in educational transitions they appear to contribute to. School staff should try to encourage lower-class families to request LGT and adjust too ambitious choices of higher-class families with low-performing students. Beyond that, this study makes an important theoretical contribution as it shows that arguments from seemingly competing theories such as rational choice and cultural reproduction theory can be fruitfully integrated to understand social inequality in educational decision-making under specific institutional circumstances.

Future research should investigate the processes through which the institutional setting shapes the decision-making of families and teachers and whether the effect of social class and, especially, of parents' cultural capital differs by institutional setting. Comparisons over educational systems that differ with regard to teachers' decision-making power, families' right to reject school propositions and requirements from governmental authorities could be effective approaches. Moreover, consequences of social inequality in families' and school staffs' use of grade retention to postpone actual transitions should be examined. If students who are retained through the dialogue finally gain access to the general track, this increases social inequality in educational opportunity. At the same time, if these higher-class students' performance decreases as compared to that of students who were not retained (Jimerson et al. 
2006), this may reduce social inequality in school performance among students in the general track. 


\section{Endnotes}

${ }^{1}$ A large extent of the sample reduction is due to missing brevet-information and parents' non-participation in the family survey. As the distributions of EGP-class are very similar in the initial sample and the analysis sample and correlations between indicators of missing values and the variables used in the analyses are very low, the results appear to be robust. Moreover, sensitivity analyses with multiple imputation via chained equations using Stata 11’s 'mi’-command provide very similar results (results available on request).

${ }^{2}$ To compute AMEs, I use the 'margins'-command implemented in Stata 11. The AME is the average of the marginal effect or discrete change effect over all observations and hence over all observed combinations of values of the other variables. For an insightful explanation of AMEs see also Williams (2012: 325). The predicted probability plots were obtained with the Stata-ado ‘mgen’ (Long and Freese 2014).

${ }^{3}$ A decrease of the AIC (Akaike's Information Criterion)-value indicates an increase of the model fit.

${ }^{4}$ This result is provided by predicted probability plots not presented in the paper (available on request). These correspond to Figure 5 but hold for families who requested LPA. 


\section{References}

Barg K (2013) The influence of students' social background and parental involvement on teachers' school track choices: Reasons and consequences. European Sociological Review 29(3): 565-579.

Becker R, Hecken AE (2009) Higher Education or Vocational Training? An Empirical Test of the Rational Action Model of Educational Choices Suggested by Breen and Goldthorpe and Esser. Acta Sociologica 52(1): 25-45.

Bénabou R, Kramarz F, and Prost C (2009) The French zones d'éducation prioritaire: Much Ado About Nothing? Economics of Education Review 28(3): 345-356.

Boudon R (1974) Education, Opportunity, and Social Inequality - Changing Prospects in Western Societies. New York: Wiley.

Bourdieu P (1966) L'école conservatrice. Les inégalités devant l'école et devant la culture. Revue Française de Sociologie 7: 325-347.

Bowles S, Gintis H (1976) Schooling in Capitalist America. New York: Basic Books.

Brauns H (1998) Bildung in Frankreich: eine Studie zum Wandel herkunfts- und geschlechtsspezifischen Bildungsverhaltens. Opladen: Leske und Budrich.

Brauns H, Steinmann S (1999) Educational Reform in France, West-Germany, and the United Kingdom. Updating the CASMIN Educational Classification. ZUMA Nachrichten 23.

Breen R, Goldthorpe, JH (1997) Explaining Educational Differentials - Towards a Formal Rational Action Theory. Rationality and Society 9(3): 275-305.

Cheadle JE, Amato PR (2011) A Quantitative Assessment of Lareau’s Qualitative Conclusions About Class, Race, and Parenting. Journal of Family Issues 32(5): 679706.

DEPP (Direction de l'évaluation, de la prospective et de la performance) (2008) Suivi des élèves du Panel 1995 au cours de leurs études secondaires. Fichier Historique 19952006. Présentation du panel et documentation. Paris: INSEE. 
Dollmann J (2011) Verbindliche und unverbindliche Grundschulempfehlungen und soziale Ungleichheiten am ersten Bildungsübergang. Kölner Zeitschrift für Soziologie und Sozialpsychologie 63(4): 431-457.

Duru-Bellat M (1996) Social inequalities in French secondary schools: From figures to theories. British Journal of Sociology of Education 17(3): 341-351.

Duru-Bellat M, Kieffer A (2001) The Democratization of Education in France: Controversy over a Topical Issue. Population: An English Selection 13(2): 189-218.

Duru-Bellat M, Jarousse J-P, and Mingat A (1993) Les Scolarités de la Maternelle au Lycée: Étapes et Processus dans la Production des Inégalités Sociales. Revue Française de Sociologie 34(1): 43-60.

Duru-Bellat M, Mingat A (1989) How do French Junior Secondary Schools Operate? Academic Achievement, Grading and Streaming of Students. European Sociological Review 5(1): 47-64.

Erikson R, Goldthorpe JH (1992) The Constant Flux: A Study of Class Mobility in Industrial Societies. Oxford: Clarendon Press.

Erikson R, Jonsson JO (1996) Explaining Class Inequality in Education: The Swedish Test Case in R. Erikson and J. O. Jonsson (ed.) Can Education Be Equalized? The Swedish Case in Comparative Perspective. Westview Press.

Esser H (1999) Soziologie. Spezielle Grundlagen 1: Situationslogik und Handeln. Frankfurt a.M.: Campus.

Horvat EM, Weininger E, and Lareau A (2003) From Social Ties to Social Capital: Class Difference in the Relations Between School and Parent Networks. American Educational Research Journal 40(2): 319-351. 
Ichou M, Vallet L-A (2011) Do All Roads Lead to Inequality? Trends in French Upper Secondary School Analysed with Four Longitudinal Surveys. Oxford Review of Education 37(2): 167-194.

Ichou M, Vallet L-A (2013) Academic Achievement, Tracking Decisions, and Their Relative Contribution to Educational Inequalities: Change Over Four Decades in France in M. Jackson (ed.) Determined to Succeed? Performance versus Choice in Educational Attainment. Stanford: University Press.

Jimerson SR, Pletcher SMW, Graydon K, Schnurr BL, Nickerson AB, and Kundert DK (2006) Beyond Grade Retention and Social Promotion: Promoting the Social and Academic Competence of Students. Psychology in the Schools 43(1): 85-97.

Karlson KB, Holm A (2011) Decomposing Primary and Secondary effects: A New Decomposition Method. Research in Social Stratification and Mobility 29(2): 221-37.

Kloosterman R, De Graaf PM (2010) Non-promotion or Enrolment in a Lower Track? The Influence of Social Background on Choices in Secondary Education for Three Cohorts of Dutch Pupils. Oxford Review of Education 36(3): 363-384.

Lareau A, Weininger E (2003) Cultural Capital in Educational Research: A Critical Assessment. Theory and Society 32(5/6): 567-606.

Long JS (1997) Regression Models for Categorical and Limited Dependent Variables. Thousand Oaks: Sage.

Long JS, Freese J (2014) Regression Models for Categorical Dependent Variables Using Stata. 3rd Edition. College Station, Texas: Stata Press.

Masson P (1994) Négociations et conflits dans le processus d'orientation des élèves de l'enseignement secondaire. Sociétés contemporaines 18-19: 165-186.

Masson P (1997) Elèves, parents d'élèves et agents scolaires dans le processus d'orientation. Revue Française de Sociologie 38(1): 119-142. 
Mood C (2010) Logistic Regression: Why We Cannot Do What We Think We Can Do, and What We Can Do About It. European Sociological Review 26(1): 67-82.

Neugebauer M (2010) Bildungsungleichheit und Grundschulempfehlung beim Übergang auf das Gymnasium: Eine Dekomposition primärer und sekundärer Herkunftseffekte. Zeitschrift für Soziologie 39(3): 202-214.

OECD (1996) Education at a glance. Analysis. Paris: OECD.

Roux S, Davaillon A (2001) Le processus d'orientation en fin de troisième - Observation des comportements des acteurs et analyse des causalités. Éducation et Formations 60: 4153.

Ryan C, Watson L (2006) Why Does Year Twelve Retention Differ Between Australian States and Territories? Australian Journal of Education 50(2): 203-219.

Schnurr BL, Kundert DK, and Nickerson AB (2009) Grade Retention: Current Decisionmaking Practices and Involvement of School Psychologists Working in Public Schools. Psychology in the Schools 46(5): 410-419.

Stocké V (2007) Explaining Educational Decision and Effects of Families' Social Class Position: An Empirical Test of the Breen-Goldthorpe Model of Educational Attainment. European Sociological Review 23(4): 505-19.

Williams R (2012) Using Stata's Margins Command to Estimate and Interpret Adjusted Predictions and Marginal Effects. The Stata Journal 12(2): 308-331. 
Figure 1: Distribution of families' requests, staff meetings' propositions and families' rejections over social class

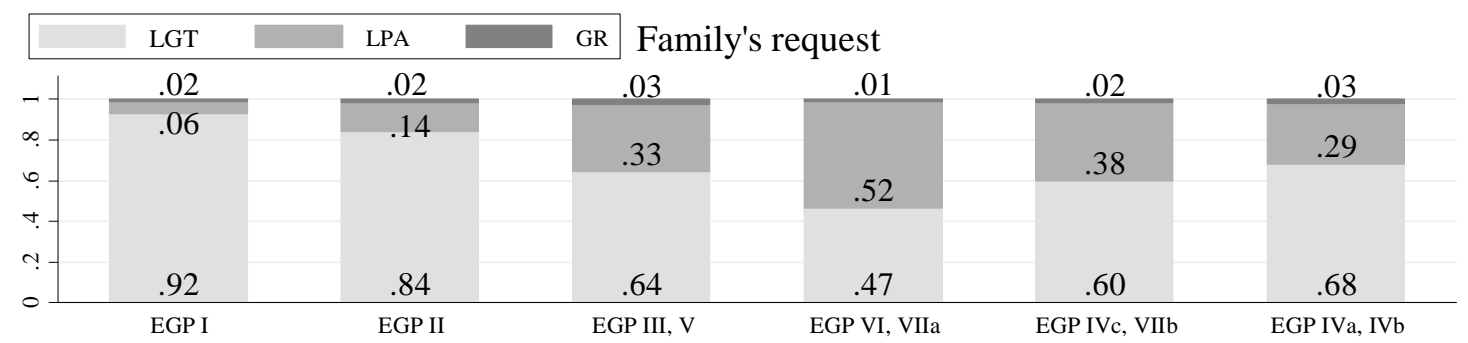

Staff meeting's proposition
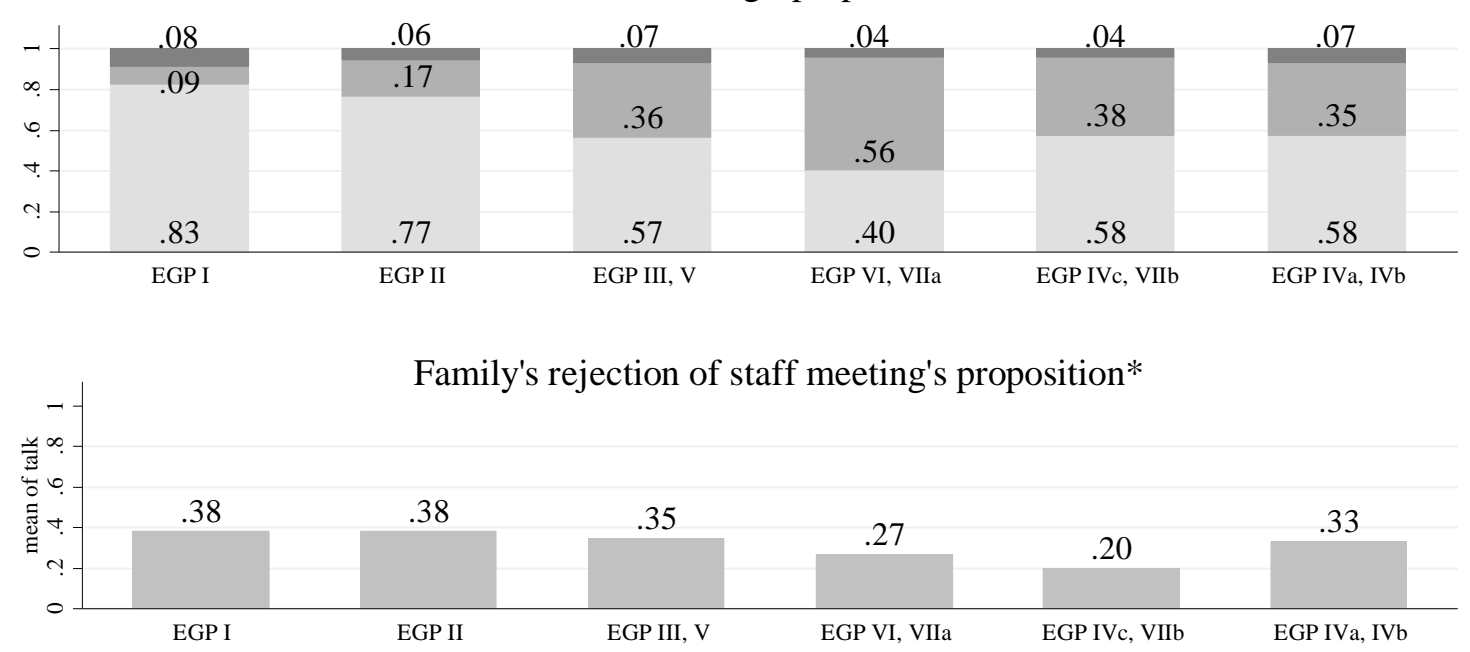

Note: *Based on sample containing families who requested LGT but were proposed LPA or GR. Source: Panel d'élèves du second degré (1995-2001); own calculations. 
Figure 2: Distribution of GPA over social class

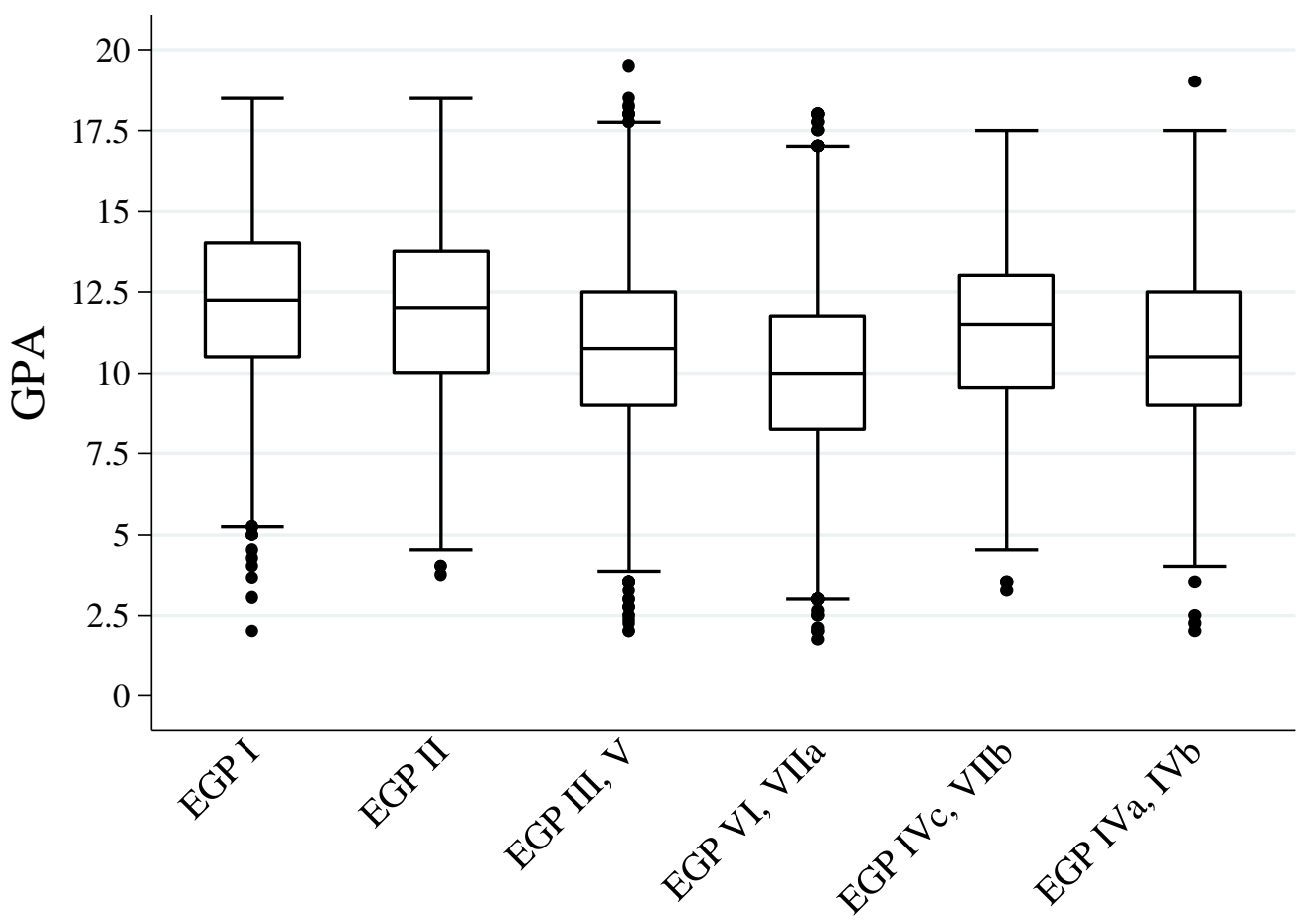

Source: Panel d'élèves du second degré (1995-2001); own calculations.

Figure 3: Distribution of previous grade repetition and parental education over social class

Grade repetition
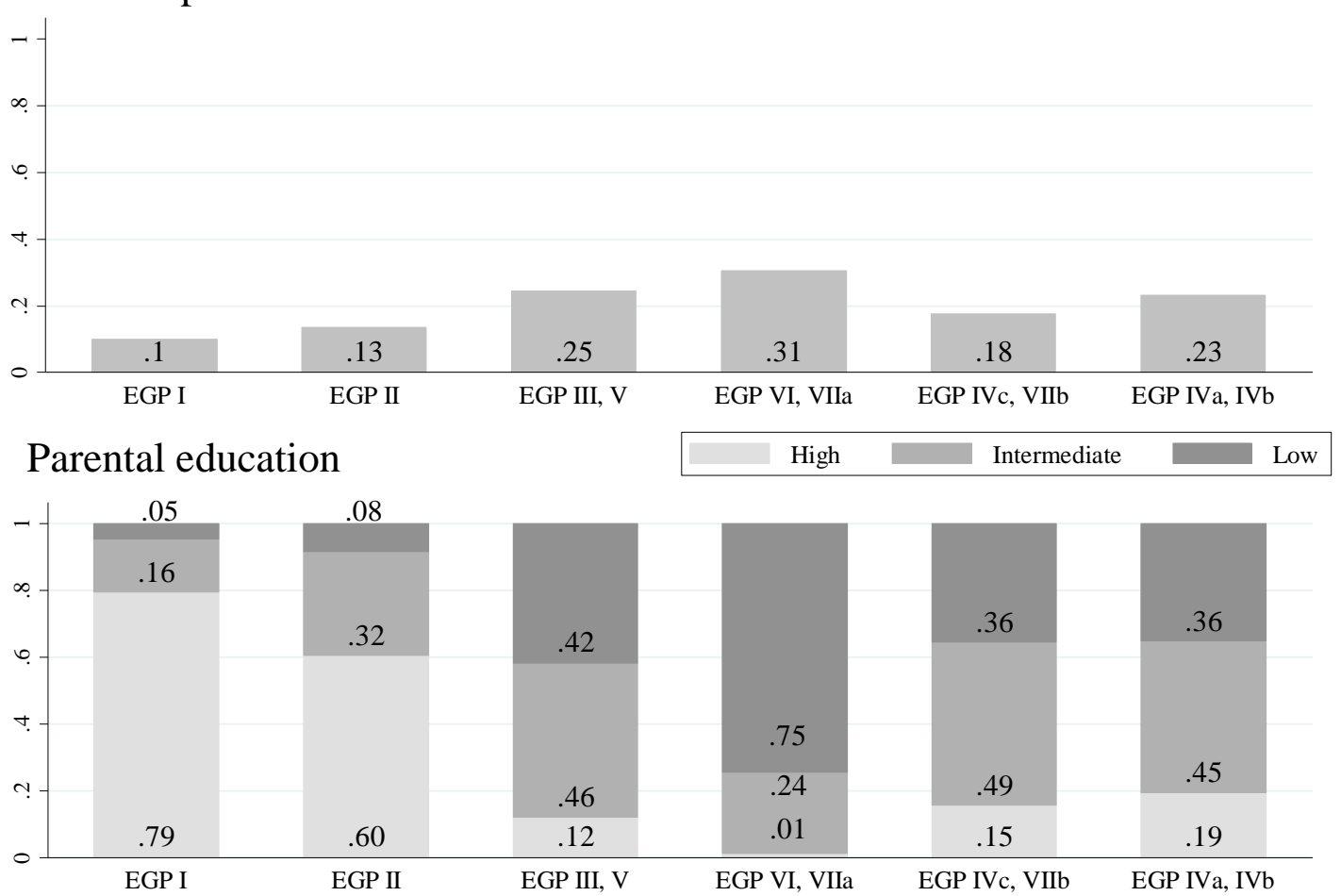

Source: Panel d'élèves du second degré (1995-2001); own calculations. 
Table 1: Multinomial logistic regression analyses of families' requests (AMEs)

\begin{tabular}{|c|c|c|c|c|c|c|}
\hline & \multicolumn{2}{|c|}{ Model 1} & \multicolumn{2}{|c|}{ Model 2} & \multicolumn{2}{|c|}{ Model 3} \\
\hline & LGT/LPA & GR/LPA & LGT/LPA & GR/LPA & LGT/LPA & GR/LPA \\
\hline \multicolumn{7}{|l|}{ Social class } \\
\hline \multicolumn{7}{|c|}{ Ref. EGP VI, VIIa, no prof. } \\
\hline EGP I & $0.449^{* * *}$ & 0.002 & $0.251^{* * *}$ & $0.021^{* * *}$ & $0.178^{* * *}$ & $0.014^{*}$ \\
\hline EGP II & $0.368^{* * *}$ & 0.008 & $0.174^{* * *}$ & $0.022^{* * *}$ & $0.101^{* * *}$ & $0.014^{*}$ \\
\hline EGP III, V & $0.170^{* * *}$ & $0.015^{* * *}$ & $0.077^{* * *}$ & $0.017^{* * *}$ & $0.049^{* * *}$ & $0.016^{* * *}$ \\
\hline EGP IVc, VIIb & $0.167^{* * *}$ & 0.005 & 0.017 & 0.008 & -0.013 & 0.007 \\
\hline EGP IVab & $0.216^{* * *}$ & $0.013^{*}$ & $0.128^{* * *}$ & $0.012^{* *}$ & $0.091^{* * *}$ & $0.010^{*}$ \\
\hline GPA & & & $0.073^{* * *}$ & $-0.010^{* * *}$ & $0.071^{* * *}$ & $-0.010^{* * *}$ \\
\hline $\begin{array}{l}\text { Previous grade } \\
\text { repetition }\end{array}$ & & & $-0.191^{* * *}$ & $-0.028^{* * *}$ & $-0.184^{* * *}$ & $-0.028^{* * *}$ \\
\hline \multicolumn{7}{|l|}{ Parental education } \\
\hline \multicolumn{7}{|l|}{ Ref. Lower } \\
\hline Intermediate & & & & & $0.053^{* * *}$ & $0.008^{*}$ \\
\hline Higher & & & & & $0.118^{* * *}$ & $0.014^{* *}$ \\
\hline$N$ & & & & & & \\
\hline$A I C$ & & & & & & \\
\hline
\end{tabular}


Figure 4: Predicted probabilities for families' request by GPA, social class and previous grade repetition
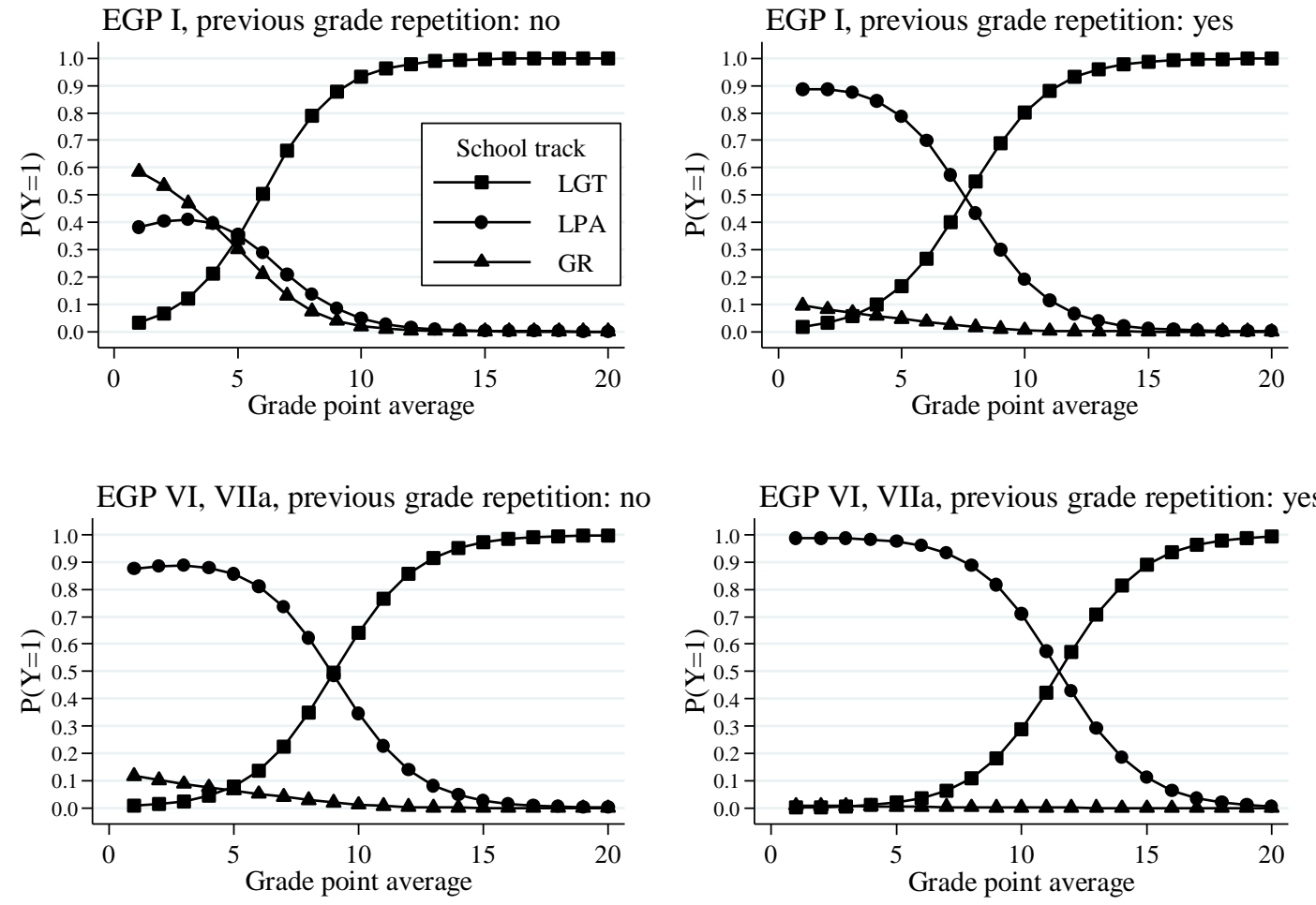

Note: Predicted probabilities obtained from Model 2, Table 1; if not indicated differently, covariates held constant at '0'. Source: Panel d'élèves du second degré (1995-2001); own calculations. 
Table 2: Multinomial logistic regression analyses of staff meetings' propositions (AMEs)

\begin{tabular}{|c|c|c|c|c|c|c|c|c|}
\hline & \multicolumn{2}{|c|}{ Model 1} & \multicolumn{2}{|c|}{ Model 2} & \multicolumn{2}{|c|}{ Model 3} & \multicolumn{2}{|c|}{ Model 4} \\
\hline & LGT/LPA & GR/LPA & LGT/LPA & GR/LPA & LGT/LPA & GR/LPA & LGT/LPA & GR/LPA \\
\hline \multicolumn{9}{|l|}{ Social class } \\
\hline \multicolumn{9}{|c|}{ Ref. EGPV I, VIIa, no prof. } \\
\hline EGP I & $0.428^{* * *}$ & $0.036^{* * *}$ & $0.161^{* * *}$ & $0.094^{* * *}$ & -0.003 & $0.036^{* * *}$ & -0.010 & $0.022^{* *}$ \\
\hline EGP II & $0.366^{* * *}$ & $0.015^{*}$ & $0.131^{* * *}$ & $0.044^{* * *}$ & 0.001 & $0.013^{*}$ & -0.007 & 0.002 \\
\hline EGP III, V & $0.162^{* * *}$ & $0.029^{* * *}$ & $0.058^{* * *}$ & $0.036^{* * *}$ & -0.001 & $0.017^{* *}$ & -0.005 & $0.013^{*}$ \\
\hline $\begin{array}{l}\text { EGP IVc, } \\
\text { VIIb }\end{array}$ & $0.200^{* * *}$ & 0.002 & 0.025 & 0.014 & 0.020 & 0.009 & 0.016 & 0.005 \\
\hline EGP IVab & $0.180^{* * *}$ & $0.028^{* *}$ & $0.085^{* * *}$ & $0.029^{* * *}$ & -0.001 & 0.006 & -0.006 & 0.001 \\
\hline GPA & & & $0.098^{* * *}$ & $-0.027^{* * *}$ & $0.051^{* * *}$ & $-0.027^{* * *}$ & $0.051^{* * *}$ & $-0.028^{* * *}$ \\
\hline Previous grad & tition & & $-0.172^{* * *}$ & $-0.076^{* * *}$ & $-0.037^{* * *}$ & $-0.044^{* * *}$ & $-0.036^{* * *}$ & $-0.044^{* * *}$ \\
\hline \multicolumn{9}{|c|}{ Family’s request } \\
\hline \multicolumn{9}{|c|}{ Ref. LPA } \\
\hline GR & & & & & 0.070 & $0.644^{* * *}$ & 0.061 & $0.642^{* * *}$ \\
\hline LGT & & & & & $0.605^{* * *}$ & $0.089^{* * *}$ & $0.597^{* * *}$ & $0.087^{* * *}$ \\
\hline \multicolumn{9}{|c|}{$\begin{array}{l}\text { Parental education } \\
\text { (Ref. Lower) }\end{array}$} \\
\hline $\begin{array}{l}\text { (Rel. Lower) } \\
\text { Intermediate }\end{array}$ & & & & & & & 0.008 & $0.014^{* *}$ \\
\hline Higher & & & & & & & 0.012 & $0.021^{* * *}$ \\
\hline$N$ & \multicolumn{2}{|c|}{11623} & \multicolumn{2}{|c|}{11623} & \multicolumn{2}{|c|}{11623} & \multicolumn{2}{|c|}{11623} \\
\hline$A I C$ & \multicolumn{2}{|c|}{18017.69} & \multicolumn{2}{|c|}{11294.11} & \multicolumn{2}{|c|}{5581.634} & \multicolumn{2}{|c|}{5549.641} \\
\hline
\end{tabular}

Note: Coefficients of control variables not shown; standard errors adjusted for school-level clustering; ${ }^{*} \mathrm{p}<0.05 ;{ }^{* *} \mathrm{p}<0.01 ;{ }^{* * *} \mathrm{p}<0.001$.

Source: Panel d'élèves du second degré (1995-2001); own calculations. 
Figure 5: Predicted probabilities for staff meetings' propositions by grade point average, social class and previous grade repetition
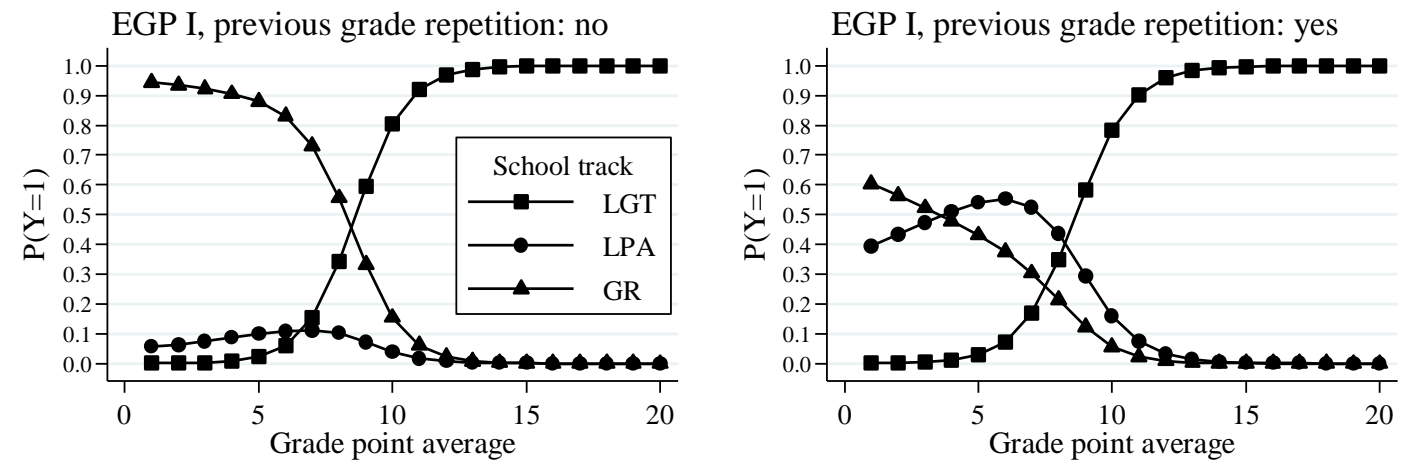

EGP VI, VIIa, previous grade repetition: no

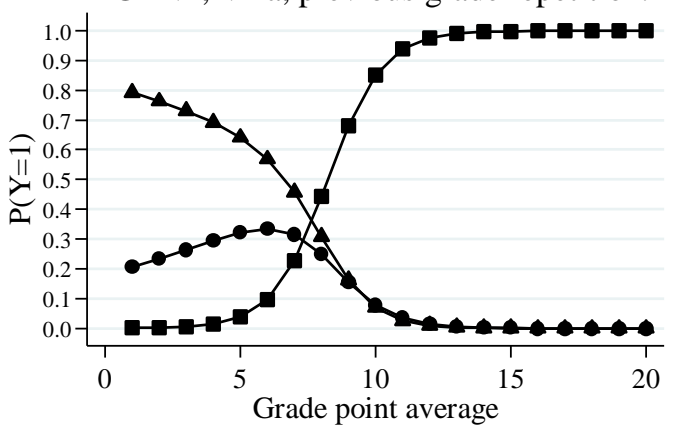

EGP VI, VIIa, previous grade repetition: yes

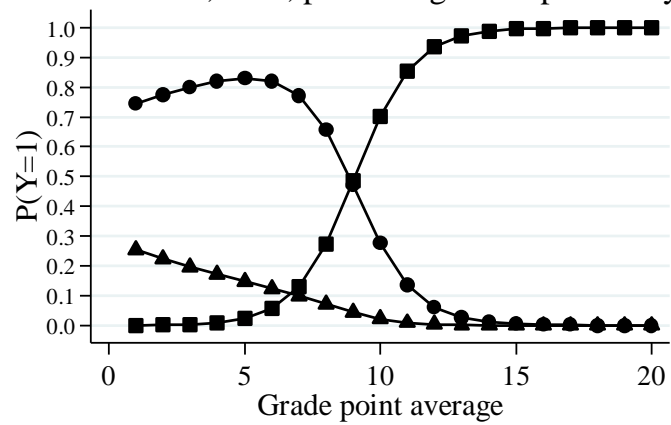

Note: Predicted probabilities obtained from Model 3, Table 2; family’s request: LGT, if not indicated differently, other covariates held constant at ' 0 '. Source: Panel d'élèves du second degré (1995-2001); own calculations. 
Table 3: Binary logistic regression analyses of families' rejection decisions (AMEs)

\begin{tabular}{lcc}
\hline & Model 1 & Model 2 \\
\hline Social class & & \\
Ref. EGP VI, VIIa, no prof. & & \\
EGP I & $0.131^{* *}$ & 0.071 \\
EGP II & $0.134^{*}$ & 0.078 \\
EGP III, V & $0.089^{*}$ & 0.063 \\
EGP IVc, VIIb & -0.056 & -0.099 \\
$\quad$ EGP IVab & 0.076 & 0.051 \\
Parental education & & \\
Ref. Lower & & $0.088^{*}$ \\
Intermediate & & 0.095 \\
$\quad$ Higher & 956 & 956 \\
\hline$N$ & 1235.5 & 1233.6 \\
AIC & & \\
\hline
\end{tabular}

Note: Coefficients of control variables not shown; standard errors adjusted for school-level clustering; ${ }^{*} \mathrm{p}<0.05 ;{ }^{* *} \mathrm{p}<0.01 ;{ }^{* * *} \mathrm{p}<0.001$. Source: Panel d'élèves du second degré (1995-2001); own calculations. 


\section{List of abbreviations}

$\begin{array}{ll}\text { AME } & \text { Average Marginal Effect } \\ \text { BEP } & \text { 'Diploma of Vocational Aptitude' } \\ \text { CAP } & \text { 'Certificate of Vocational Aptitude' } \\ \text { GPA } & \text { Grade Point Average } \\ \text { GR } & \text { Grade retention } \\ \text { LGT } & \text { General track } \\ \text { LPA } & \text { Vocational track }\end{array}$

